\title{
SISTEM PAKAR PENYAKIT MATA MERAH BERBASIS WEB MENGGUNAKAN METODE DECISION TREE DENGAN FORWARD CHAINING
}

\author{
(Expert System of Red Eye Disease Based on Web Using Decision Tree with Forward \\ Chaining Method)
}

\author{
Tri Erna Suharningsih*, I Gede Pasek Suta Wijaya, dan Ario Yudo Husodo \\ Program Studi Teknik Informatika, Fakultas Teknik, Universitas Mataram. \\ Jl. Majapahit 62, Mataram, Lombok, NTB-INDONESIA. \\ Email: trierna.s@gmail.com,gpsutawijaya@unram.ac.id, ario@ti.ftunram.ac.id
}

\begin{abstract}
This paper presents expert system disease of the red eye web-based using the decision tree with forward chaining algorithms. The aims are to design and to implement web-based expert system of disorders of the red eye (disease), and to provide a second opinion web tool based for diagnosing the red eye (disease). The system was built using framework codeigniter with php and html. The experimental results show that the system has run well which is indicated by valid black box achievements, 55\% of conformity to experts from the Faculty of Medicine of the University of Mataram and 4.19 of five leakage scale of MOS parameter. It means that the expert system of red eye disease has been work properly and potentially to be implemented for the community.
\end{abstract}

Keywords: Expert System, Red Eye Disease, Decision Tree, Forward Chaining, Web-Based System.

*Penulis korespondensi

\section{Pendahuluan}

Mata adalah salah satu panca indra yang dimiliki manusia untuk melihat, mata juga merupakan organ inti dalam keberlangsungan kegiatan yang dilakukan oleh manusia. Mata dapat mengalami gangguan baik itu yang dapat mengurangi daya penglihatan maupun tidak. Salah satu gangguan mata yang sering didapati dalam masyarakat luas yaitu gangguan mata yang disertai dengan keadaan mata yang memerah (pink eye/ red eye). Kondisi ini dapat disebabkan oleh bakteri, virus, alergi, bahan kimia, maupun benda asing yang ada di sekitar lingkungan seperti asap, debu, pembersih rumah tangga, spray berbagai macam, dan benda asing lainnya[1].

Menurut hasil survey dari kementerian kesehatan Republik Indonesia tahun 2014, penduduk provinsi Nusa Tenggara Barat yang mengalami gangguan penglihatan mencapai 0,5\% dari total penduduk, hal ini merupakan hasil survei secara keseluruhan dari berbagai macam penyakit mata. Belum adanya data statistik penderita penyakit mata merah secara khusus ini menandakan bahwa masyarakat luas saat ini masih memandang remeh tentang mata merah, masyarakat menganggap mata merah dapat diatasi dengan obat tetes biasa saja. Masyarakat desa pada umumnya juga akan kesulitan untuk berkonsultasi secara langsung kepada pakar mata, karena para pakar biasanya berada pada daerah perkotaan. Kemudian biaya untuk konsultasi kepada pakar juga membutuhkan biaya yang tidak murah, sehingga masyarakat ekonomi menengah ke bawah akan lebih memilih untuk mengabaikan penyakit mata merah yang diderita nya. Padahal pada fakta nya mata merah dapat menjarah ke dalam penyakit berbahaya lainnya, bahkan jika dibiarkan ataupun diatasi dengan cara yang tidak tepat penderita akan mengalami gangguan penglihatan yang disertai maupun tidak disertai dengan penurunan kemampuan penglihatan, pada kondisi yang paling parah dapat menyebabkan kebutaan permanen. Padahal menurut WHO sebagai organisasi kesehatan dunia $80 \%$ gangguan penglihatan dan kebutaan diseluruh dunia dapat dicegah, dengan hasil yang baik dan biaya yang efektif [2].

Oleh itu masyarakat perlu untuk mendapatkan bantuan dalam mengenali penyakit mata merah yang diderita. Bantuan pengenalan tersebut dititik tekankan pada pengumpulan gejala-gejala yang dialami, dimana beberapa gejala dapat mengakibatkan suatu penyakit dari mata merah. Maka dibutuhkan suatu sistem yang dapat mengenali gangguan mata merah yang diderita, yang dapat diakses dengan mudah dan dengan biaya yang minim bahkan gratis. 
Sistem pakar berbasis web ini bertujuan agar masyarakat dapat mengenali gangguan mata merah yang diderita nya lebih awal. Dengan sistem pakar berbasis web akan mempermudah melakukan akses terhadap sistem pakar, sehingga sistem pakar ini dapat diakses tanpa terpengaruh waktu dan tempat asalkan dapat terhubung dengan jaringan internet. Sistem pakar ini akan dibangun dengan pembuatan decision tree dengan metode forward chaining terlebih dahulu. Penggunaan decision tree ini berfungsi sebagai teknik dalam proses pencarian sehingga dapat menyederhanakan akuisisi pengetahuan yang ada dalam sistem pakar ini. Metode forward chaining dipilih dengan maksud agar pengguna tidak perlu harus mengetahui jenis penyakit terlebih dahulu, karena dengan metode ini penelusuran akan dilakukan dari masalah gejala yang dialami kepada solusi dugaan penyakit yang diderita. Sehingga penderita dapat mengenali penyakit yang diderita nya serta melakukan pengobatan dini. Jika pada kondisi mata merah yang disertai penurunan penglihatan, maka harus segera dilakukan pemeriksaan secara mendalam karena dapat mengakibatkan kebutaan. Dengan begitu gangguan tersebut dapat diatasi dengan tepat.

\section{TINJAUAN PUSTAKA}

Penelitian tentang aplikasi sistem pakar untuk mendiagnosis penyakit mata menggunakan metode Naïve Bayes Classifier[3]. Dari hasil percobaan, prosentase kesesuaian diagnosis sebesar $83 \%$. Kelemahannya beberapa gejala dalam sistem ini kurang dimengerti oleh masyarakat awam, karena menggunakan bahasa medis yang jarang didengar.

Sistem pakar penyakit THT menggunakan metode forward chaining sebagai mesin inferensi dan berbasis web juga telah berhasil dilakukan[4]. Berdasarkan pengujian sistem, tingkat akurasi metode forward chaining untuk mendeteksi penyakit THT yaitu 100. Kelemahan dalam sistem ini, terdapat beberapa gejala yang sulit dimengerti oleh masyarakat awam, karena tidak bisa dilihat maupun dirasakan secara langsung [4].

Sistem pakar tentang penyakit mata pada manusia menggunakan metode forward chaining juga telah dibangun, namun sistem ini belum mencantumkan secara pasti persentase keberhasilan dari sistem yang dibuat [5].

Berdasarkan penelitian-penelitian yang telah dilakukan tersebut, sistem pakar penyakit mata merah menggunakan metode Decision tree dengan Forward chaining sangat mungkin dilakukan. Sistem pakar penyakit mata merah dibangun berbasiskan web, sehingga pengguna akan mudah untuk melakukan diagnosa penyakit mata merah berdasarkan gejalagejala yang ada, dapat dilakukan secara gratis, kapan saja, dan dimana saja selama terkoneksi dengan jaringan internet. Penyajian gambar dari beberapa jenis gejala maupun penyakit akan memberikan pemahaman yang mudah dimengerti oleh pengguna dalam proses melakukan diagnosa.

\section{MetOde Usulan}

Secara umum proses penelitian untuk pembuatan Sistem Pakar Penyakit Mata Merah ditunjukkan pada Gambar 1.

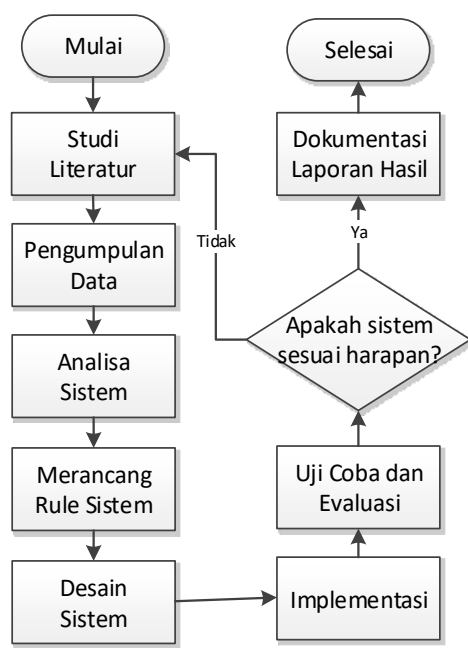

Gambar 1. Diagram alir penelitian

Gambar 1 merupakan gambaran aliran proses pembuatan Sistem Pakar Penyakit Mata Merah. Pada penelitian ini menggunakan model incremental, model incremental merupakan model untuk pengembangan sistem yang didasari pada requirement yang dibagi menjadi beberapa bagian sehingga pengembangan nya secara bertahap.

\subsection{Studi Literatur}

Study literature digunakan untuk membantu penulis dalam penelitian ini. Study literature berupa kajian pustaka beserta dasar teori yang terkait, meliputi: sistem pakar, decision tree dengan metode forward chaining, serta nama-nama penyakit mata merah, serta gejala-gejala dari penyakit mata merah yang ada. Study literature dilakukan dengan mempelajari buku-buku, literatur, jurnal, mengakses beberapa situs terkait, bahkan konsultasi kepada pakar kesehatan[6].

\subsection{Pengumpulan Data}

Data yang digunakan untuk membuat sistem pakar penyakit mata merah ini meliputi data-data penyakit mata merah yang disertai gejala-gejala dari penyakit 
mata merah itu sendiri. Data penyakit dan gejala didapat dari hasil wawancara tanya dan jawab yang dilakukan dengan seorang pakar mata[7].

\subsection{Analisa Sistem}

Sistem pakar penyakit mata merah yang dibuat dapat dijelaskan secara garis besar seperti Gambar 2 .

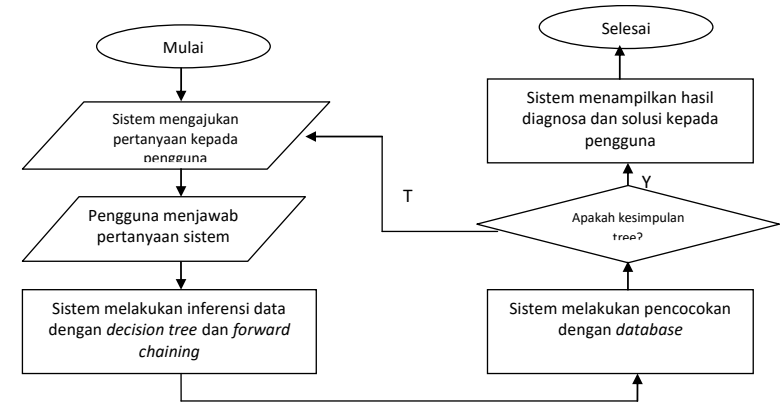

Gambar 2. Diagram alir sistem berjalan

\subsection{Perancangan Rule Sistem}

Decision tree dibangun dengan menggunakan entropy dan informasi gain, karena mudah diinterpretasikan, efisien, dan memiliki tingkat akurasi yang dapat diterima[8]. Namun pada kasus yang diteliti ini, entropy dan informasi gain tidak dapat diterapkan dalam pembangunan decision tree. Penggunaan entropy dan information gain ini diterapkan pada kasus yang memiliki jumlah kesimpulan yang jauh lebih sedikit dibandingkan jumlah pertanyaan (node). Dimana pada kasus yang diteliti sekarang kesimpulan (dalam hal ini data penyakit) berbanding lebih sedikit dibandingkan jumlah pertanyaan (dalam hal ini data gejala), yaitu sejumlah 20 data penyakit dan 32 data gejala, sehingga entropy dan informasi gain tidak dipilih dalam proses pembuatan decision tree sistem pakar mata merah ini, melainkan dengan cara penentuan persentase kemunculan suatu gejala terhadap gejala lain pada penyakit-penyakit dalam database sistem. Sebelumnya akan ditentukan gejala utama dari penyakit-penyakit mata ini, yaitu gejala dengan penurunan penglihatan atau tidak. Kemudian akan ditentukan gejala dengan persentase terbesar yang muncul menyertai gejala utama tersebut, setelah itu ditentukan gejala dengan persentase terbesar yang muncul menyertai gejala yang sudah terpenuhi sebelumnya, begitu seterusnya sampai kesimpulan didapatkan. Contoh penjabaran proses pembangunan decision tree pada penelitian ini dijelaskan pada Gambar 3.

\subsection{Desain Sistem}

Desain sistem adalah tahapan perancangan sistem pakar penyakit mata merah yang dibangun. Perancangan ini dijelaskan pada point 1 dan 2 .

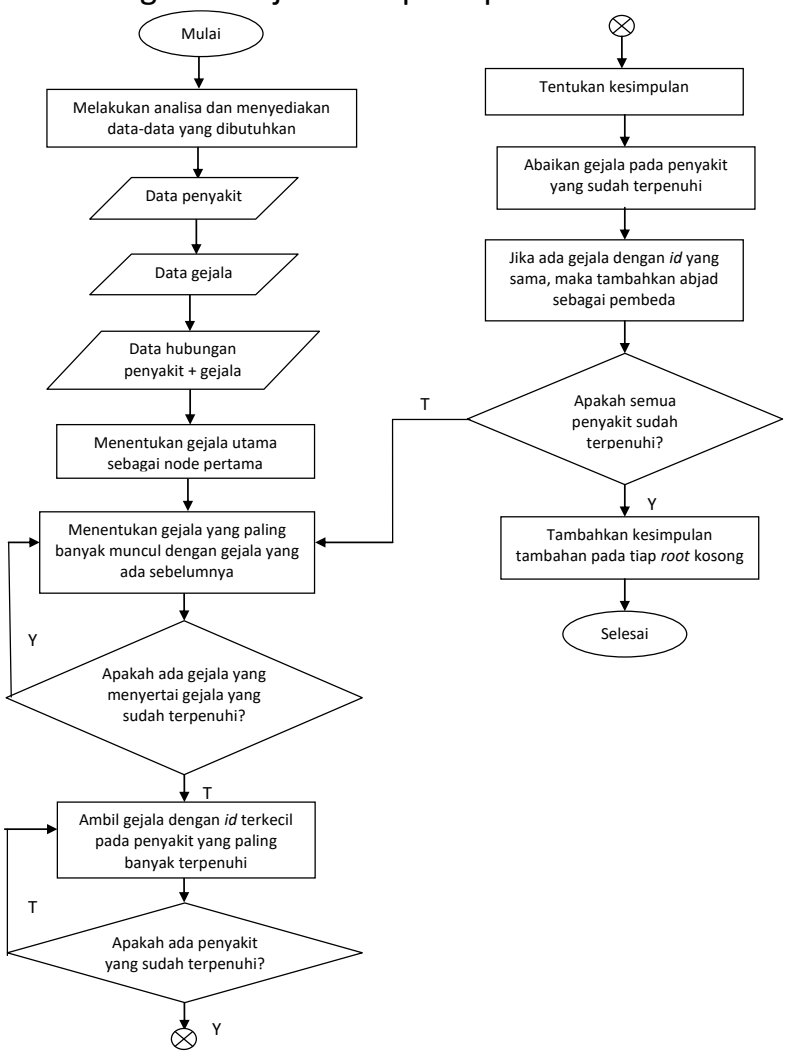

Gambar 3. Rule sistem pakar usulan

\subsubsection{Use case diagram}

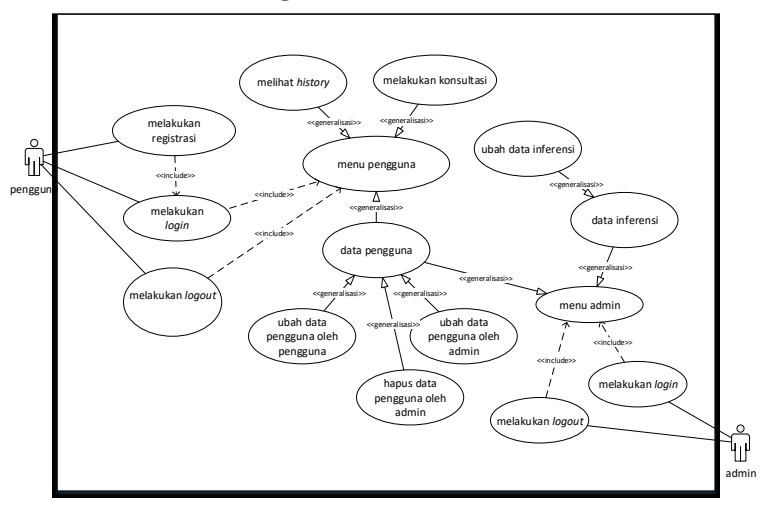

Gambar 4. Use case diagram sistem pakar usulan

Gambar 4. merupakan use case diagram dari sistem pakar penyakit mata merah yang menjelaskan interaksi yang dilakukan antara aktor pengguna dan aktor admin dengan sistem. Aktor pengguna harus mengisi registrasi untuk mendapatkan username dan password yang digunakan untuk mengakses sistem pakar penyakit mata merah. Registrasi yang telah selesai dilakukan, pengguna dapat melakukan login dengan 
memasukkan username dan password yang telah diisi pengguna saat melakukan registrasi sebelumnya. pengguna yang berhasil login dapat melakukan konsultasi, melihat history penyakit, serta dapat melakukan perubahan pada profile miliknya.

Aktor admin harus melakukan login dengan username dan password yang telah dimiliki. Login yang berhasil dilakukan admin, dapat memberikan admin tersebut akses untuk menghapus atau mengubah data pengguna, serta dapat melakukan perubahan pada data inferensi.

\subsubsection{Entity Relation Diagram}

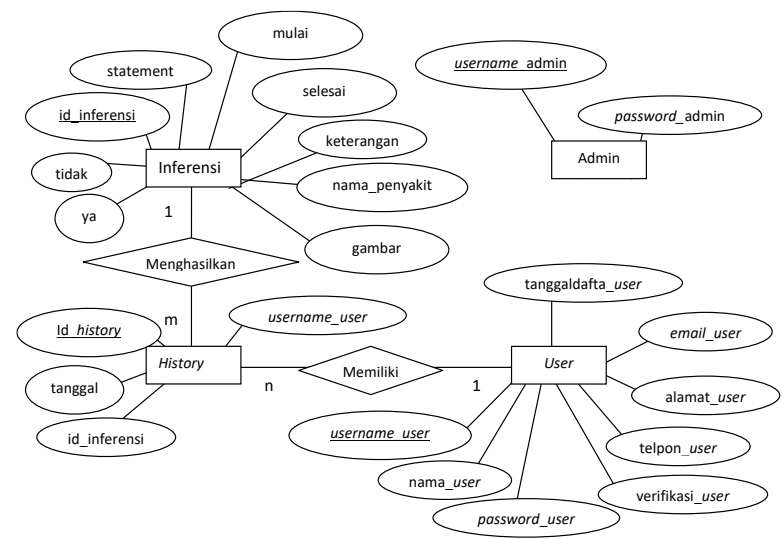

Gambar 5. Entity relation diagram sistem pakar usulan

Gambar 5 merupakan ERD dari sistem pakar penyakit mata merah yang menggambarkan relasi menghasilkan menyatakan hubungan antara entitas inferensi dan entitas history yang bersifat $1: \mathrm{m}$, artinya satu inferensi dapat menghasilkan banyak history dan sebaliknya banyak history dapat menghasilkan satu inferensi. Relasi memiliki menyatakan hubungan antara entitas history dan entitas user yang bersifat $\mathrm{n}: 1$, artinya banyak history memiliki satu user dan sebaliknya satu user memiliki banyak history. Entitas admin tidak memiliki relasi dengan entitas lainnya.

\section{Hasil Pengujian dan Pembahasan}

Pengujian merupakan tahap pengukuran keberhasilan sistem pakar penyakit mata merah. Tahapan pengujian ini dilakukan dengan metode black box, pengujian teoritis atas perbandingan diagnosa pakar dengan diagnosa sistem dan pengujian user friendly dengan parameter MOS (Mean Opinion Score).

\subsection{Hasil Pengujian dengan Metode Black Box.}

Metode pengujian black box ditujukan untuk pengujian fungsionalitas pada sistem pakar penyakit mata merah. Pengujian fungsi-fungsi menggunakan metode black box pada sistem pakar penyakit mata merah dapat dilihat pada Tabel 1 . Hasil pengujian yang valid adalah fungsi yang menghasilkan pesan tertentu dan bekerja sesuai yang diharapkan.

TABLE I. HASIL PENGUJIAN BLACK BOX

\begin{tabular}{|l|c|}
\hline \multicolumn{1}{|c|}{ Fungsi } & $\begin{array}{c}\text { Hasil } \\
\text { Pengujian }\end{array}$ \\
\hline Fungsi form registrasi pengguna & Valid \\
\hline Fungsi form login pengguna & Valid \\
\hline $\begin{array}{l}\text { Fungsi laman pengguna } \\
\text { (update profile dan proses } \\
\text { konsultasi) }\end{array}$ & Valid \\
\hline $\begin{array}{l}\text { Fungsi form login admin } \\
\text { Fungsi laman admin } \\
\text { (manajemen data inferensi dan } \\
\text { pengguna) }\end{array}$ & Valid \\
\hline
\end{tabular}

Berdasarkan hasil pengujian pada Tabel I tersebut dapat disimpulkan bahwa dari segi fungsionalitas sistem pakar penyakit mata merah berjalan dengan baik. Fungsi-fungsi tersebut telah diuji dengan berbagai kondisi dan input data yang berbeda-beda.

\subsection{Hasil Pengujian Kesesuaian Diagnosa Sistem dengan Diagnosa Pakar}

Pengujian ini dilakukan oleh seorang pakar mata, pakar tersebut melakukan diagnosa dari gejala-gejala yang muncul pada sistem. Pengujian ini bertujuan untuk mengetahui seberapa besar kesesuaian diagnosa pakar dan diagnosa sistem.

Pakar diberikan 20 kasus yang berisi beberapa gejala yang merunut pada sistem. Pengujian dilakukan dengan terlebih dahulu menjelaskan mengenai sistem kepada pakar tersebut, kemudian diberikan kasuskasus yang berisi gejala-gejala yang dialami maupun tidak dialami oleh penderita penyakit mata. Hasil diagnosa pakar kemudian dibandingkan dengan hasil kesimpulan diagnosa sistem dapat dilihat pada Tabel II.

Berdasarkan dari 60 kasus pengujian pada Tabel II didapatkan kesesuaian perbandingan diagnosa pakar dengan sistem adalah 33 percobaan dengan hasil sesuai dan 27 percobaan dengan hasil tidak sesuai. Kesesuaian hasil pengujian perbandingan diagnosa pakar dengan diagnosa sistem adalah sebesar 55\%. Tingkat kesesuaian diagnosa yang rendah dikarenakan faktorfaktor keilmuan yang dimiliki oleh pakar. Pakar mendiagnosa pasien dengan mempertimbangkan riwayat penyakit pasien, sebab akibat terjadinya suatu gangguan mata merah yang dialami pasien, gejala yang dimiliki pasien, serta faktor klinis pasien. Sedangkan sistem mendiagnosa pasien hanya bertumpu pada gejala yang dimiliki pasien. Sebagai contoh, pada 
percobaan ke-17 dan percobaan ke-18 terdapat hasil data yang terlihat janggal. Dikarenakan menurut data

table II. Hasil Pengujian Kesesuaian Diagnosa Sistem DENGAN DIAGNOSA PAKAR

\begin{tabular}{|c|c|c|c|}
\hline $\begin{array}{l}\text { Uji } \\
\mathrm{Ke}-\end{array}$ & $\begin{array}{c}\text { Kesimpulan } \\
\text { Diagnosa Pakar }\end{array}$ & $\begin{array}{c}\text { Kesimpulan } \\
\text { Diagnosa } \\
\text { Sistem }\end{array}$ & Ket. \\
\hline 1. & Pinguekula & Pinguekula 95\% & Sesuai \\
\hline 2. & Pinguekula & $\begin{array}{c}\text { Subconjunctival } \\
\text { haemorrhage } \\
33 \%\end{array}$ & $\begin{array}{l}\text { Tidak } \\
\text { Sesuai }\end{array}$ \\
\hline 3. & Iridocyclitis, iritis & $\begin{array}{l}\text { Iridocyclitis, } \\
\text { iritis 95\% }\end{array}$ & Sesuai \\
\hline 4. & Ulkus cornea & $\begin{array}{c}\text { Ulkus cornea } \\
95 \%\end{array}$ & Sesuai \\
\hline 5. & Ulkus cornea & $\begin{array}{c}\text { Ulkus cornea } \\
87 \%\end{array}$ & Sesuai \\
\hline 6. & Dacryocystitis & $\begin{array}{c}\text { Dacryocystitis } \\
95 \%\end{array}$ & Sesuai \\
\hline 7. & Iridocyclitis, iritis & $\begin{array}{l}\text { Iridocyclitis, } \\
\text { iritis } 42 \%\end{array}$ & Sesuai \\
\hline 8. & Ulkus cornea & $\begin{array}{c}\text { Ulkus cornea } \\
37 \%\end{array}$ & Sesuai \\
\hline 9. & Episkleritis & $\begin{array}{c}\text { Subconjunctival } \\
\text { haemorrhage } \\
75 \%\end{array}$ & $\begin{array}{l}\text { Tidak } \\
\text { Sesuai }\end{array}$ \\
\hline 10. & Pinguekula & Pinguekula 25\% & Sesuai \\
\hline 11. & Ulkus cornea & $\begin{array}{c}\text { Glaucoma akut } \\
70 \% \\
\end{array}$ & $\begin{array}{l}\text { Tidak } \\
\text { Sesuai }\end{array}$ \\
\hline 12. & Keratitis & Pterygium 61\% & $\begin{array}{l}\text { Tidak } \\
\text { Sesuai }\end{array}$ \\
\hline 13. & $\begin{array}{c}\text { Kerato- } \\
\text { conjunctivitis sicca }\end{array}$ & $\begin{array}{c}\text { Kerato- } \\
\text { conjunctivitis } \\
\text { sicca } 84 \%\end{array}$ & Sesuai \\
\hline 14. & Dacryoadenitis & $\begin{array}{c}\text { Dacryoadenitis } \\
8 \%\end{array}$ & $\begin{array}{l}\text { Tidak } \\
\text { Sesuai }\end{array}$ \\
\hline 15. & $\begin{array}{c}\text { Conjunctivitis, } \\
\text { allergy }\end{array}$ & $\begin{array}{c}\text { Dacryoadenitis } \\
33 \%\end{array}$ & $\begin{array}{l}\text { Tidak } \\
\text { Sesuai }\end{array}$ \\
\hline 16. & Keratitis & $\begin{array}{l}\text { Iridocyclitis, } \\
\text { iritis } 57 \%\end{array}$ & $\begin{array}{l}\text { Tidak } \\
\text { Sesuai }\end{array}$ \\
\hline 17. & Keratitis & Keratitis 95\% & Sesuai \\
\hline 18. & Keratitis & Pterygium 95\% & $\begin{array}{l}\text { Tidak } \\
\text { Sesuai }\end{array}$ \\
\hline 19. & Keratitis & Keratitis $75 \%$, & Sesuai \\
\hline 20. & Dacryoadenitis & $\begin{array}{c}\text { Conjunctivitis, } \\
\text { allergy } 88 \%\end{array}$ & $\begin{array}{l}\text { Tidak } \\
\text { Sesuai }\end{array}$ \\
\hline 21. & Pinguekula & Pinguekula 95\% & Sesuai \\
\hline 22. & Pinguekula & $\begin{array}{c}\text { Subconjunctival } \\
\text { haemorrhage } 33 \%\end{array}$ & $\begin{array}{l}\text { Tidak } \\
\text { Sesuai }\end{array}$ \\
\hline 23. & Keratitis & $\begin{array}{c}\text { Iridocyclitis, } \\
\text { iritis } 95 \% \\
\end{array}$ & $\begin{array}{l}\text { Tidak } \\
\text { Sesuai }\end{array}$ \\
\hline 24. & Ulkus cornea & $\begin{array}{c}\text { Ulkus cornea } \\
95 \%\end{array}$ & Sesuai \\
\hline 25. & $\begin{array}{c}\text { Kerato- } \\
\text { conjunctivitis sicca }\end{array}$ & $\begin{array}{c}\text { Ulkus cornea } \\
87 \%\end{array}$ & $\begin{array}{l}\text { Tidak } \\
\text { Sesuai }\end{array}$ \\
\hline 26. & Dacryocystitis & $\begin{array}{c}\text { Dacryocystitis } \\
95 \%\end{array}$ & Sesuai \\
\hline
\end{tabular}

\begin{tabular}{|c|c|c|c|}
\hline 27. & Iridocyclitis, iritis & $\begin{array}{c}\text { Iridocyclitis, } \\
\text { iritis } 42 \%\end{array}$ & Sesuai \\
\hline 28. & Ulkus cornea & $\begin{array}{c}\text { Ulkus cornea } \\
37 \%\end{array}$ & Sesuai \\
\hline 29. & Episkleritis & $\begin{array}{c}\text { Subconjunctival } \\
\text { haemorrhage } \\
75 \%\end{array}$ & $\begin{array}{l}\text { Tidak } \\
\text { Sesuai }\end{array}$ \\
\hline 30. & Pterygium & Pinguekula $25 \%$ & $\begin{array}{l}\text { Tidak } \\
\text { Sesuai }\end{array}$ \\
\hline 31. & Keratitis & $\begin{array}{c}\text { Glaucoma akut } \\
70 \% \\
\end{array}$ & $\begin{array}{l}\text { Tidak } \\
\text { Sesuai }\end{array}$ \\
\hline 32. & Ulkus cornea & Pterygium 61\% & $\begin{array}{l}\text { Tidak } \\
\text { Sesuai }\end{array}$ \\
\hline 33. & $\begin{array}{c}\text { Kerato- } \\
\text { conjunctivitis sicca }\end{array}$ & $\begin{array}{c}\text { Kerato- } \\
\text { conjunctivitis } \\
\text { sicca } 84 \%\end{array}$ & Sesuai \\
\hline 34. & Pterygium & $\begin{array}{c}\text { Dacryoadenitis } \\
8 \% \\
\end{array}$ & $\begin{array}{l}\text { Tidak } \\
\text { Sesuai }\end{array}$ \\
\hline 35. & Pterygium & $\begin{array}{c}\text { Dacryoadenitis } \\
33 \%\end{array}$ & $\begin{array}{l}\text { Tidak } \\
\text { Sesuai }\end{array}$ \\
\hline 36. & Iridocyclitis, iritis & $\begin{array}{c}\text { Iridocyclitis, } \\
\text { iritis } 57 \%\end{array}$ & Sesuai \\
\hline 37. & Pinguekula & Pinguekula 75\% & Sesuai \\
\hline 38. & Pterygium & Pinguekula 91\% & $\begin{array}{l}\text { Tidak } \\
\text { Sesuai }\end{array}$ \\
\hline 39. & Dacryocystitis & Chalazion 85\% & $\begin{array}{l}\text { Tidak } \\
\text { Sesuai }\end{array}$ \\
\hline 40. & Normal & Sehat $90 \%$ & Sesuai \\
\hline 41. & Trachoma & Trachoma 95\% & Sesuai \\
\hline 42. & Entropion & Entropion 95\% & Sesuai \\
\hline 43. & Keratitis & $\begin{array}{c}\text { Kerato- } \\
\text { conjunctivitis } \\
\text { sicca } 95 \% \\
\end{array}$ & $\begin{array}{l}\text { Tidak } \\
\text { Sesuai }\end{array}$ \\
\hline 44. & Endophtalmitis & $\begin{array}{c}\text { Endophtalmitis } \\
95 \%\end{array}$ & Sesuai \\
\hline 45. & $\begin{array}{c}\text { Kerato- } \\
\text { conjunctivitis sicca }\end{array}$ & Pterygium 95\% & $\begin{array}{l}\text { Tidak } \\
\text { Sesuai }\end{array}$ \\
\hline 46. & Ulkus cornea & $\begin{array}{c}\text { Ulkus cornea } \\
95 \%\end{array}$ & Sesuai \\
\hline 47. & Glaucoma akut & $\begin{array}{c}\text { Glaucoma akut } \\
95 \% \\
\end{array}$ & Sesuai \\
\hline 48. & Keratitis & $\begin{array}{c}\text { Iridocyclitis, } \\
\text { iritis } 95 \%\end{array}$ & $\begin{array}{l}\text { Tidak } \\
\text { Sesuai }\end{array}$ \\
\hline 49. & Dacryocystitis & $\begin{array}{c}\text { Dacryocystitis } \\
95 \% \\
\end{array}$ & Sesuai \\
\hline 50. & $\begin{array}{c}\text { Conjunctivitis, } \\
\text { viral }\end{array}$ & $\begin{array}{c}\text { Conjunctivitis, } \\
\text { viral } 95 \%\end{array}$ & Sesuai \\
\hline 51. & $\begin{array}{c}\text { Conjunctivitis, } \\
\text { allergy }\end{array}$ & $\begin{array}{c}\text { Conjunctivitis, } \\
\text { allergy } 95 \%\end{array}$ & Sesuai \\
\hline 52. & $\begin{array}{c}\text { Conjunctivitis, } \\
\text { bacterial }\end{array}$ & Blepharitis 95\% & $\begin{array}{l}\text { Tidak } \\
\text { Sesuai }\end{array}$ \\
\hline 53. & Hordeolum & Hordeolum 95\% & Sesuai \\
\hline 54. & $\begin{array}{c}\text { Conjunctivitis, } \\
\text { bacterial }\end{array}$ & $\begin{array}{l}\text { Conjunctivitis, } \\
\text { bacterial } 95 \%\end{array}$ & Sesuai \\
\hline 55. & $\begin{array}{c}\text { Conjunctivitis, } \\
\text { bacterial }\end{array}$ & $\begin{array}{l}\text { Conjunctivitis, } \\
\text { mycosis } 95 \%\end{array}$ & $\begin{array}{l}\text { Tidak } \\
\text { Sesuai }\end{array}$ \\
\hline 56. & Pinguekula & Pinguekula 95\% & Sesuai \\
\hline 57. & Pterygium & $\begin{array}{c}\text { Subconjunctival } \\
\text { haemorrhage } 95 \%\end{array}$ & $\begin{array}{l}\text { Tidak } \\
\text { Sesuai }\end{array}$ \\
\hline
\end{tabular}




\begin{tabular}{|c|c|c|c|}
\hline 58. & Hordeolum & $\begin{array}{c}\text { Dacryoadenitis } \\
95 \%\end{array}$ & $\begin{array}{c}\text { Tidak } \\
\text { Sesuai }\end{array}$ \\
\hline 59. & Keratitis & Keratitis 95\% & Sesuai \\
\hline 60. & Chalazion & Chalazion 95\% & Sesuai \\
\hline
\end{tabular}

yang sudah dikumpulkan sebelumnya, percobaan ke17 memiliki diagnosa Keratitis 95\% dan percobaan ke18 seharusnya memiliki diagnosa Pterygium 95\%. Akan tetapi berdasarkan diagnosa pakar percobaan ke-17 dan percobaan ke-18 memiliki diagnosa yang sama yaitu Keratitis, hal ini karena pada dasarnya Keratitis dan Pterygium memiliki sejumlah besar kesamaan pada data gejala. Jumlah gejala pada Keratitis adalah 11 gejala, jumlah gejala pada Pterygium adalah 13 gejala, dan data jumlah gejala yang sama pada kedua penyakit ini adalah 8 gejala. Rincian dari pembahasan ini dapat dilihat pada Tabel III.

TABlE III. TABel Gejala PercobaAn yang DiJAdikan PEMBAHASAN

\begin{tabular}{|c|c|c|c|}
\hline No & $\begin{array}{l}\text { Uji } \\
\text { Ke - }\end{array}$ & Gejala Percobaan & Keterangan \\
\hline 1. & 17 & 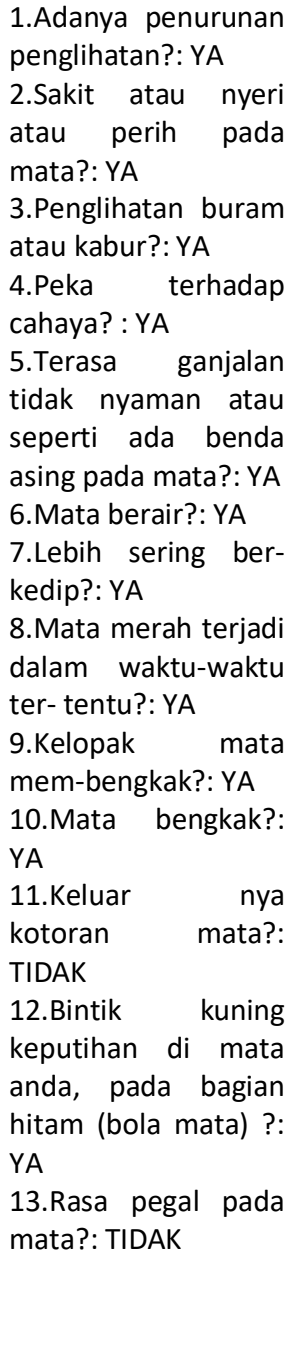 & 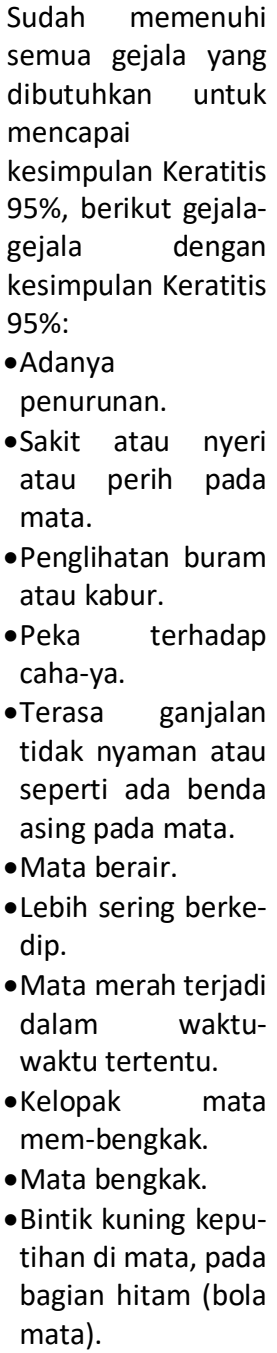 \\
\hline
\end{tabular}

\begin{tabular}{|c|c|c|c|}
\hline 2. & 18 & $\begin{array}{l}\text { 1.Adanya penurunan } \\
\text { penglihatan?: YA } \\
\text { 2.Sakit atau nyeri } \\
\text { atau perih pada } \\
\text { mata?: YA } \\
\text { 3.Penglihatan buram } \\
\text { atau kabur?: YA } \\
\text { 4.Peka terhadap } \\
\text { cahaya? : YA } \\
\text { 5. Terasa ganjalan } \\
\text { tidak nyaman atau } \\
\text { seperti ada benda } \\
\text { asing pada mata?:YA } \\
\text { 6.Mata berair?: YA } \\
\text { 7.Lebih sering berke- } \\
\text { dip?:YA } \\
\text { 8. Mata merah terjadi } \\
\text { dalam waktu-waktu } \\
\text { ter-tentu?: YA } \\
\text { 9.Kelopak mata } \\
\text { mem- bengkak?: } \\
\text { TIDAK } \\
\text { 10.Rasa panas pada } \\
\text { mata?: YA } \\
\text { 11. Mata kering?:YA } \\
\text { 12.Dehidrasi } \\
\text { berlebih-an?: YA } \\
\text { 13.Rasa gatal pada } \\
\text { mata?:YA } \\
\text { 14.Bintik kuning } \\
\text { keputihan di mata } \\
\text { anda pada bagian } \\
\text { putih?:YA }\end{array}$ & $\begin{array}{l}\text { Sudah memenuhi } \\
\text { se-mua gejala yang } \\
\text { dibu-tuhkan untuk } \\
\text { mencapai } \\
\text { kesimpulan } \\
\text { Pterygium 95\%, } \\
\text { berikut gejala-gejala } \\
\text { dengan kesim-pulan } \\
\text { Pterygium 95\%: } \\
\text {-Adanya } \\
\text { penurunan. } \\
\text { - Sakit atau nyeri } \\
\text { atau perih pada } \\
\text { mata. } \\
\text {-Penglihatan } \\
\text { buram atau } \\
\text { kabur. } \\
\text {-Peka terhadap } \\
\text { caha-ya. } \\
\text {-Terasa ganjalan ti- } \\
\text { dak nyaman atau } \\
\text { seperti ada benda } \\
\text { asing pada mata. } \\
\text {-Mata berair. } \\
\text { - Lebih sering ber- } \\
\text { kedip. } \\
\text {-Mata merah } \\
\text { terjadi dalam } \\
\text { waktu-waktu } \\
\text { tertentu. } \\
\text { - Rasa panas pada } \\
\text { mata. } \\
\text {-Mata kering. } \\
\text {-Dehidrasi berlebi- } \\
\text { han. } \\
\text { - Rasa gatal pada } \\
\text { mata. } \\
\text {-Bintik kunu-tihan anda pada } \\
\text { bagian putih. } \\
\text { mata }\end{array}$ \\
\hline
\end{tabular}

Melalui data Tabel III dapat disimpulkan bahwa pada kasus yang menjadi penelitian diagnosa seorang pakar didasarkan oleh faktor klinis yang dimiliki oleh seorang pasien. Diagnosa pakar tidak hanya bergantung pada materi data-data gejala yang sudah tertulis saja, tetapi harus melalui pemeriksaan klinis juga. Hal inilah yang menjadi perbedaan diagnosa pakar dengan diagnosa sistem.

\subsection{Hasil Pengujian dengan Parameter MOS (Mean Opinion Score).}

Pengujian ini dilakukan oleh beberapa orang yang akan menggunakan sistem. Pengujian ini bertujuan untuk mengetahui kualitas user friendly sistem terhadap pengguna. 
Pengujian dilakukan oleh 30 responden yang berasal dari mahasiswa. Pengujian dilakukan dengan menjelaskan maksud pengujian sistem kepada responden terlebih dahulu, kemudian responden mencoba sistem secara langsung. Responden dapat memberikan penilaian terhadap sistem melalui kuesioner.

Hasil kuesioner responden akan dihitung dengan parameter MOS (Mean Opinion Score)[9] untuk mendapatkan kesimpulan hasil pengujian. Berikut isi dari kuesioner tersebut:

1.Tampilan dan desain sistem ini sederhana dan menarik.

2. Sistem ini mudah digunakan.

3. Sistem ini memiliki kecocokan font, warna dan background pada setiap halaman.

4. Sistem ini memiliki konten yang rapi.

5. Navigasi dan menu pada sistem ini cukup sederhana.

Dari isi kuesioner tersebut, responden diminta untuk memberikan penilaian dengan pilihan sesuai Tabel IV.

TABLE IV. MEAN OPINION SCORE

\begin{tabular}{|c|c|c|c|}
\hline Jawaban & Keterangan & $\begin{array}{c}\text { Bobot Nilai } \\
(\mathbf{B i})\end{array}$ & Kelompok \\
\hline SS & Sangat Setuju & 5 & Good \\
\hline S & Setuju & 4 & Good \\
\hline KS & Kurang Setuju & 3 & Neutral \\
\hline TS & Tidak Setuju & 2 & Bad \\
\hline STS & Sangat Tidak Setuju & 1 & Bad \\
\hline
\end{tabular}

Berdasarkan penilaian kuesioner tersebut, dilakukan perhitungan skor rata-rata jawaban yang diberikan responden pada setiap atribut pertanyaan. Skor rata-rata tersebut dapat dihitung dengan persamaan (1).

$$
\text { mean } p_{i}=\frac{\sum s_{i} \cdot B_{i}}{n}
$$

Dimana mean $\mathrm{p}_{\mathrm{i}}$ menyatakan rata-rata skor setiap atribut pertanyaan, $S_{i}$ menyatakan jumlah responden yang memilih setiap atribut jawaban, $B_{i}$ menyatakan bobot setiap atribut pertanyaan, dan $\mathrm{n}$ menyatakan jumlah responden. Untuk mencari Mean Opinion Score atau mencari total skor rata-rata yang diberikan responden pada seluruh atribut pertanyaan dapat dihitung dengan persamaan (2).

$$
M O S=\frac{\sum_{i=1}^{k} \operatorname{Mean} p_{i}}{k}
$$

Dimana MOS menyatakan total skor rata-rata seluruh atribut pertanyaan, dan k menyatakan jumlah atribut pertanyaan. Pengujian dengan parameter MOS sistem pakar penyakit mata merah ini dapat dilihat pada Tabel V.

\begin{tabular}{|c|c|c|c|c|c|c|c|c|}
\hline $\begin{array}{l}N \\
0\end{array}$ & Pertanyaan & $\begin{array}{l}\text { SS } \\
\text { (5) }\end{array}$ & $\begin{array}{c}S \\
(4)\end{array}$ & $\begin{array}{l}\text { KS } \\
\text { (3) }\end{array}$ & $\begin{array}{l}\text { TS } \\
\text { (2) }\end{array}$ & $\begin{array}{l}\text { STS } \\
(1)\end{array}$ & $\begin{array}{l}\text { To- } \\
\text { tal }\end{array}$ & $\begin{array}{l}\text { Me- } \\
\text { an pi }\end{array}$ \\
\hline 1 & Pertanyaan 1 & 12 & 17 & 1 & & & 30 & 4.36 \\
\hline 2 & Pertanyaan 2 & 5 & 21 & 4 & & & 30 & 4.03 \\
\hline 3 & Pertanyaan 3 & 9 & 16 & 5 & & & 30 & 4.13 \\
\hline 4 & Pertanyaan 4 & 7 & 21 & 2 & & & 30 & 4.16 \\
\hline 5 & Pertanyaan 5 & 9 & 21 & & & & 30 & 4.3 \\
\hline & Sub total & 42 & 96 & 12 & & & 150 & $\begin{array}{c}20.9 \\
8\end{array}$ \\
\hline \multicolumn{8}{|c|}{ MOS (Mean Opinion Score) } & 4.19 \\
\hline
\end{tabular}

table V. Pengujian Dengan Parameter Mos

Berdasarkan hasil pengujian MOS yang dilakukan oleh 30 responden, didapatkan hasil $\mathrm{MOS}=4.19$. Rincian penilaian hingga MOS dapat dilihat pada Tabel 4.14, menunjukkan bahwa sistem pakar penyakit mata merah ini memiliki kualitas user friendly yang baik (hasil uji MOS $\geq 4.00$ ).

\section{Penutup}

Kesimpulan yang dapat diambil dari sistem pakar mata merah ini adalah:

1. Berdasarkan hasil pengujian black box pada web sistem pakar penyakit mata merah, semua fungsi dapat berjalan dengan baik dan benar, pengujian dilakukan dengan input data yang berbeda-beda, sehingga menunjukkan bahwa fungsi yang ada dalam sistem pakar penyakit mata merah ini telah berjalan sesuai fungsinya.

2. Sistem pakar penyakit mata merah ini dapat melakukan diagnosa berbagai penyakit mata merah yang diderita pengguna dengan persentase kesesuaian dengan diagnosa pakar mencapai 55\%.

3. Berdasarkan hasil pengujian MOS (Mean Opinion Score) yang dilakukan pada 30 responden (MOS = 4.19), menunjukkan bahwa sistem pakar penyakit mata merah ini telah berjalan dengan tampilan yang baik (hasil uji MOS $\geq 4.00$ ).

Saran yang dapat diambil dari sistem pakar mata merah ini adalah:

1. Meningkatkan kesesuaian diagnosa sistem dengan pakar menggunakan komponen faktor-faktor keilmuan yang dimiliki oleh pakar, seperti mempertimbangkan riwayat penyakit pasien, sebab akibat terjadinya suatu gangguan mata merah yang dialami pasien, gejala yang dimiliki pasien, serta faktor klinis pasien. 
2. Mengembangkan sistem pakar berbasis web, yang tidak hanya mencakup mata merah saja, dengan mencakup berbagai macam penyakit, akan memudahkan masyarakat untuk memahami penyakit yang diderita sehingga dapat meningkatkan taraf kesehatan di masyarakat.

3. Membangun sebuah sistem yang dapat mengakuisisi data-data penyakit secara dinamis, untuk mempersingkat waktu pembangunan sistem yang lebih besar di masa yang akan datang.

\section{Daftar Pustaka}

[1] Anonim, 2015, Mengantisipasi Mata Merah, Available: www.alodokter.com.

[2] Anonim, 2014, Infodatin Situasi Gangguan Penglihatan dan Kebutaan, Pusat Data Dan Informasi Kementerian Kesehatan RI, Available:www.depkes.go.id.

[3] W. Setiawan, "Sistem Pakar Diagnosis Penyakit Mata Menggunakan Naïve Bayes Classifier", Universitas Trunojoyo Madura, Madura. Indonesia, 2014.

[4] W. Verina, "Penerapan Metode Forward Chaining untuk Mendeteksi Penyakit THT", Universitas Potensi Utama, Indonesia, 2015.
[5] Hamdani, "Sistem Pakar Untuk Diagnosa Penyakit Mata Pada Manusia", Universitas Mulawarman, Samarinda. Indonesia, 2010.

[6] A. Suryadi, "Rancang Bangun Aplikasi Sistem Pakar Diagnosa Penyakit Mata Manusia Dengan Menggunakan Metode Forward Chaining", Universitas Muhammadiyah Ponorogo, Ponorogo. Indonesia, 2012.

[7] J. Pasaribu, "Implementasi Sistem Pakar Untuk Diagnosa Penyakit Mata Pada Manusia", Politeknik Piksi Ganesha, Bandung, Bandung. Indonesia, 2015.

[8] T. Purworusmiadi, Induksi Decision Tree[pdf]. Available

FTP: http://mfile.narotama.ac.id/files/Tubagus\%20Purworusmiadi/Kumpulan\%File\%20PDF/I3-ID3.pdf.

[9] Y. Permana, I. G. P. S. Wijaya, dan F. Bimantoro, "Sistem Pakar Diagnosa Penyakit Mata Menggunakan Metode Certainty Factor Berbasis Android," J. Comput. Sci. Informatics Eng., vol. 1, no. 1, hal. 1-10, 2018. 